\title{
Constructing technology finance platform of Chinese high-tech industry development zones
}

\author{
Zhihong Lin ${ }^{1, a}$, Jiaqi Zou ${ }^{2, b}$ \\ ${ }^{1}$ School of Business and Administration, North China Electric Power University, Baoding, China \\ ${ }^{2}$ School of Business and Administration, North China Electric Power University, Baoding, China \\ aemail:Izh13730225252@163.com, bemail:12354zjq@163.com
}

Keywords: High-tech Zone; Combination of Technology and Finance; Integration Platform Vision

\begin{abstract}
Combination of technology and finance is one of the most important factors to future global economic development. China currently has more than 80 state-level high-tech industrial development zone, demonstrates the high-tech zone is the best choice for the integration of science and technology financial in China. Based on the advanced experience of United States, This paper analysis of the plight of China High-tech corporate finance, Then this study proposed the establishment of Trinity national High-tech zone in China financial integration platform vision
\end{abstract}

\section{The concept of science and technology and financial integration of science and technology financial and high-tech industry development zone.}

The concept of Technology and Finance was first proposed by Changwen Zhao (2009). He believes systemic Technology and Finance was a series of financial instruments to promote the development of scientific, technological achievements and high-tech industries. The financial system, monetary policy, financial services and innovative arrangements is a system provided by the financial resources to scientific and technological innovation activities of various governmental body corporate, market, social intermediary agencies and their behavior in the event of technological innovation financing process composed of the national Science and technology innovation important part of the system and the financial system. it can be seen, Technology and Finance to solve the financial instruments is not a simple innovation, technology corporate finance and other issues, but focuses on a platform to build the system, everything can be used resource integration.

\section{US tech financial experience}

China established the first High-Tech Development Zone in Beijing June 1988. Far later, by 2010, China has established a total of 83 high-tech zones, almost all provinces in the country have established their own state-level high-tech technological Development Zone. As the leading world's most economically developed countries and the global technology industry, the development of science and technology enterprises in the United States thanks to its sound financial system. American financial development model of Silicon Valley technology combining science and technology is the world's financial model. American financial development in science and technology road nearly half a century, there is a lot we can learn from the experience

\section{Developed Credit Guarantee System}

Founded in 1953, the United States Small Business Administration (SBA), specializes in providing low-interest micro-loans to SME, while local financial institutions to provide joint guarantees and interest subsidies. SBA is a federal agency of the US Congress to approve permanent, the person in charge appointed by the president, reporting directly to the President, SBA funding appropriation by Congress each year. SBA in the country established 96 outlets, guarantee high efficiency and small technology companies to provide low cost. Enterprise usually requires 
only four programs can get loan guarantees, In addition, the United States there is a considerable improvement of the credit guarantee system, including the Small Business Administration, a regional guarantee system by the local government-run and community-guarantee system. This top-down coverage of the credit guarantee system for small technology companies financing has brought great convenience.

\section{Professional Technology Venture Bank}

The United States has a large number of technology start-ups specializing in venture investment bank. Where Silicon Valley Bank is the world's largest tech venture bank, is the world's first commercial bank technology start-ups. Silicon Valley Bank's business almost all offer a variety of financial services for high-tech industries and high-tech innovative enterprises. Unlike other ordinary bank, Silicon Valley Bank perennial focus on computer network technology, biological sciences, electronics and information technology in the growth phase of the high-tech enterprises in these areas has accumulated a large number of professionals with experience, judging by the emerging future development of enterprises to We decided to invest in the direction of, and in addition to the loan, but also to direct investment by companies, such as technology companies to receive stock options to acquire equity and equity value-added benefits.

\section{Professional and Efficient Venture Capital Market}

US government encourage venture capital, given its large number of preferential policies in 1993, the provisions of the United States holding shares of high-tech SMEs 5 years (including 5 years), the tax rate of only 14\%, to promote high-tech venture capital industry development has played a positive role. So that scientific and technological innovation US venture capital is highly developed. In 2000, the US venture total investment reached \$ 100 billion. Mature professional venture for the development prospects of scientific and technological enterprises tend to judge accurately, has a huge network of customers. At the same times they will give companies developing the necessary advice and recommendations to provide quality financial intermediation and professional support.

\section{Difficulties China High-tech Industrial Development Zone faces in Technology and Finance}

For most small and medium start-ups or in the emerging class of technology companies, bank loans is still their most important means of financing. This situation will not change much in the short term. And because these companies are in the start-up period, risky and risk control is difficult, and most such enterprises unable to obtain full and no collateral, the banks due to various reasons such enterprises are reluctant to lend, or not enough the amount of loans. Tech companies are often unable to obtain bank loans in full and stable to carry out research and business activities

Chinese government departments at present, banks, investment funds. Lack of guarantee between a platform and various intermediary organic integration, leading enterprises and projects as well as information on intellectual property rights can not be effectively shared among various entities, such as corporate credit history and financial transactions in different banks, and its patented technology and other related information and relevant departments. When enterprises have financing needs, it is hard to have a platform to do that information sharing. First of all, this situation makes it impossible to do the project, loan application, subsidies, listed cultivation, the government recommended the introduction of the various steps in a venture capital institutions and efficient service platform at once. Second, the current Bank of China can not do like the United States Silicon Valley Bank as lines of communication open so that timely information to monitor risks and improve the venture capital institutions. More information when banks and venture capital or separated, which is often the source of information asymmetry risk.

Emerging technology companies, especially start-up or growing small and medium enterprises is different from traditional science and technology industry companies, from a wide range of risks they face and more difficult to guard against them. For now, China's emerging technology 
companies facing exposures. Since there is no precedent for the application of emerging technologies, the market outlook is often difficult to estimate. In many cases lack of advanced technology seemingly mature market audience.

\section{Construction Technology and Finance financing platform}

As the world's first Bank of Science and Technology, Silicon Valley Bank is the world's largest technology bank, it has achieved great success in decades of development, and also greatly promoted the development of Silicon Valley technology companies. Bank of science and technology business model has been recognized in the world wide area. Some commercial banks China has established S \& T Bank in some areas, and to some extent eased the tech business loans difficult problem. China combined with their actual development of technology banking, and high-tech zones have a natural coupling. Tech Development Zone in the establishment of technology banks should have the following characteristics

High-tech Zone perfect guarantee system should be supplemented by policy-oriented business, that policy credit guarantee agencies and local government guarantees preferential policies to support high-tech zone as the main guarantee system. Policy-based guarantee institutions advantages: First, it is more abundant capital, operating norms and guidance, professional and strong, can play the role of the United States from the SBA or associations of such JCG official agencies locally. They strictly regulate the examination and approval for policy guidance and high-tech innovation and improve the team of experts and better risk control system can support high-tech zone technology enterprises demand from major guarantee. Secondly, there has long been inequalities guarantee institutions and banks or the process of doing. Especially after the financial crisis, commercial banks and mutual guarantee institutions introduced a number of discriminatory policies. Policy credit guarantee institutions can avoid this storm strength to some extent, improve efficiency guarantee.

In the world, venture capital is very important for the start-up of science and technology enterprises a financing tool. The introduction of high-tech zones in venture capital, can serve as an important complement to other than banks, and there is a complementary relationship between the bank and venture capital. According to the current mature experience of some domestic high-tech development zones, innovation and entrepreneurship to government capital injection of shares, the introduction of private capital, professional tech venture capital firms can not only be an important complement to bank loans to corporate finance, and its innovative guiding significance, is an important part of the high-tech financial model

\section{Acknowledgement}

In this paper, the research was the Initial result of Sicencs \& Technology Finance which belong to Scientific and Technological Planning Project of Hebei Province (Project No. 15457648D).

\section{References}

[1] Kortum S, Lerner J. Does venture capital spur innovation.[R], National Bureau of Economic Research, 1998.

[2] Levine R. Finance and growth: theory and evidence[J]. Handbook of economic growth, 2005,1: 865-934.

[3] Levine R, Zervos S. Stock markets, banks, and economic growth[J]. American economic review, 1998: 537-558.

[4] Leoncini R. The nature of long-run technological change: innovation, evolution and technological systems[J]. Research Policy, 1998,27(1): 75-93.

[5] MacMillan I C, Siegel R, Narasimha P N. Criteria used by venture capitalists to evaluate new 
venture proposals [J]. Journal of Business venturing, 1986, 1(1): 119-128.

[6] Murray G C. Evolution and change: an analysis of the first decade of the UK venture [J]. Journal of Business Finance \& Accounting, 1995,22(8): 1077-1106.

[7] Myers S C. The capital structure puzzle[J], The journal of finance, 1984, 39(3): 574-592.

[8] Myers S C, Majluf N S. Corporate financing and investment decisions when firms have information that investors do not have[J]. Journal of financial economics, 1984,13(2):187-221.

[9] Nelson R. National innovation systems: a comparative analysisfJ]. University of Illinois at Urbana-Champaign's Academy for Entrepreneurial Leadership Historical Research Reference in Entrepreneurship, 1993.

[10] Ou C, Haynes G W. Acquisition of additional equity capital by small firms-findings from the National Survey of Small Business Finances[J]. Small Business Economics, 2006, 27(2-3):157-168.

[11] Samitas A G,Kenourgios D F. Entrepreneurship, small and medium size business markets and European economic integration[J]. Journal of Policy Modeling, 2005,27(3): 363-374. 